\title{
JANARISMO EM FOCO: A REPRESENTAÇÃO FOTOGRÁFICA DA CIDADE DE MACAPÁ DURANTE A FORMAÇÃO DO TERRITÓRIO DO AMAPÁ (1944-1956)
}

\author{
JANARISMO IN FOCUS: THE PHOTOGRAPHIC REPRESENTATION OF THE \\ MACAPÁ CITY DURING OF THE AMAPÁ'S TERRITORY FORMATION (1944-1956)
}

Luciana Macêdo ${ }^{1}$

http://lattes.cnpq.br/8939537303557508

Recebido em 12 de março de 2019

Aceito em 25 de novembro de 2019

RESUMO: A intenção deste trabalho é abordar, através de fotografias, as transformações da paisagem da cidade de Macapá durante a formação do Território Federal do Amapá, doravante denominado de TFA, no período de 1944-1956. A criação do território deu-se no ano de 1943. Em princípio, a cidade escolhida para ser a capital do novo território foi Amapá, devido à sua localização central no território, próximo à Base Aérea Americana e ao fato de que nela se concentrava a elite pecuarista da região. A transferência da capital do município do Amapá para Macapá se dá em 1944, quando Janary Gentil Nunes assumiu o governo do Território até 1956. Distante geograficamente dos grandes centros metropolitanos e políticos do Brasil, durante esse período o Território teve grande afirmação econômica, o que permitiu o crescimento de sua capital. $\mathrm{O}$ artigo tem por objetivo discutir transformações na paisagem de Macapá, as quais indicam que a administração de Janary Gentil Nunes tinha uma governabilidade orientada por concepções relativas a modernização de Macapá. Para cumprir com esse intento são analisadas as fotografias referentes a construção de três prédios que acabaram por se tornarem símbolos desse contexto modernizante, obras que modificaram significativamente o perfil da cidade: o Macapá Hotel (1944), o Grupo Escolar Barão do Rio Branco (1946) e o Colégio Amapaense (1952).

Palavras-chave: história, modernidade, Janary Gentil Nunes

\begin{abstract}
The intention of this work is to approach, through photographs, the transformation of the city of Macapa during the formation of the Federal Territory of Amapá, hereafter called TFA, in the period of 1944-1956. The creation of the territory took place in 1943. At first, the city chosen to be the capital of the new territory was Amapá, because of its central location, the proximity of the American Air Base and the fact that the region's livestock elite was concentrated there. The transfer of the capital of the municipality of Amapa to Macapá in 1944, when Janary Gentil Nunes assumed the government of the Territory until 1956. Geographically distant of the great metropolitan and political centers of Brazil, during that time period the Territory had great economic affirmation, which allowed the growth of its capital. The article aims to discuss changes in the landscape of Macapa, With indicate that the administration of Janary Gentil Nunes had a governability guided by conceptions concerning the modernization of Macapa. To fulfill this goal, the photographs referring to the construction of three buildins that eventually became symbols of this modernizing context are analyzed, works that significantly changed the city's profile: the Macapá Hotel (1944), the Barão do Rio Branco School Group (1946) and the
\end{abstract}

${ }^{1}$ Doutoranda em Urbanismo. Mestrado Profissional em Administração pela Universidade Federal Fluminense. Professor da Universidade Federal do Amapá. E-mail: proflucianamacedo@gmail.com. 
Amapaense College (1952).

Keywords: history, modernity, Janary Gentil Nunes

\section{GÊNESE E CONSTRUÇÃo HISTÓRICA DA CIDADE DE MACAPÁ}

Em 2019 Macapá comemora seus setenta e cinco anos como capital amapaense. Este artigo apresenta-se como uma pequena análise visual da gênese desta cidade, como sede do então ente federativo Território Federal do Amapá.

Para compreender as transformações ocorridas na cidade de Macapá durante a gestão de Janary Gentil Nunes (1944-1956) é necessário compreender o seu papel no âmbito da história do Amapá. Porto (2014) afirma que todas as transformações sofridas pela cidade foram exógenas, desde a sua gênese. Sua história está dividida em três fases: sua criação como vila no período colonial, sua existência como Comarca do Grão-Pará e, por fim, como capital do TFA. Segundo Lobato (2013), a primeira urbanização da região foi realizada por um destacamento militar, em 1738, para a defesa da região contra a invasão dos franceses, holandeses e britânicos. De acordo com Luna (2017), em 1752 chegaram por determinação do Marquês de Pombal, famílias açorianas e funchalenses vindas das ilhas de Portugal, fortalecendo a ocupação portuguesa na região. A vila de São José de Macapá foi fundada no dia 04 de fevereiro de 1758.

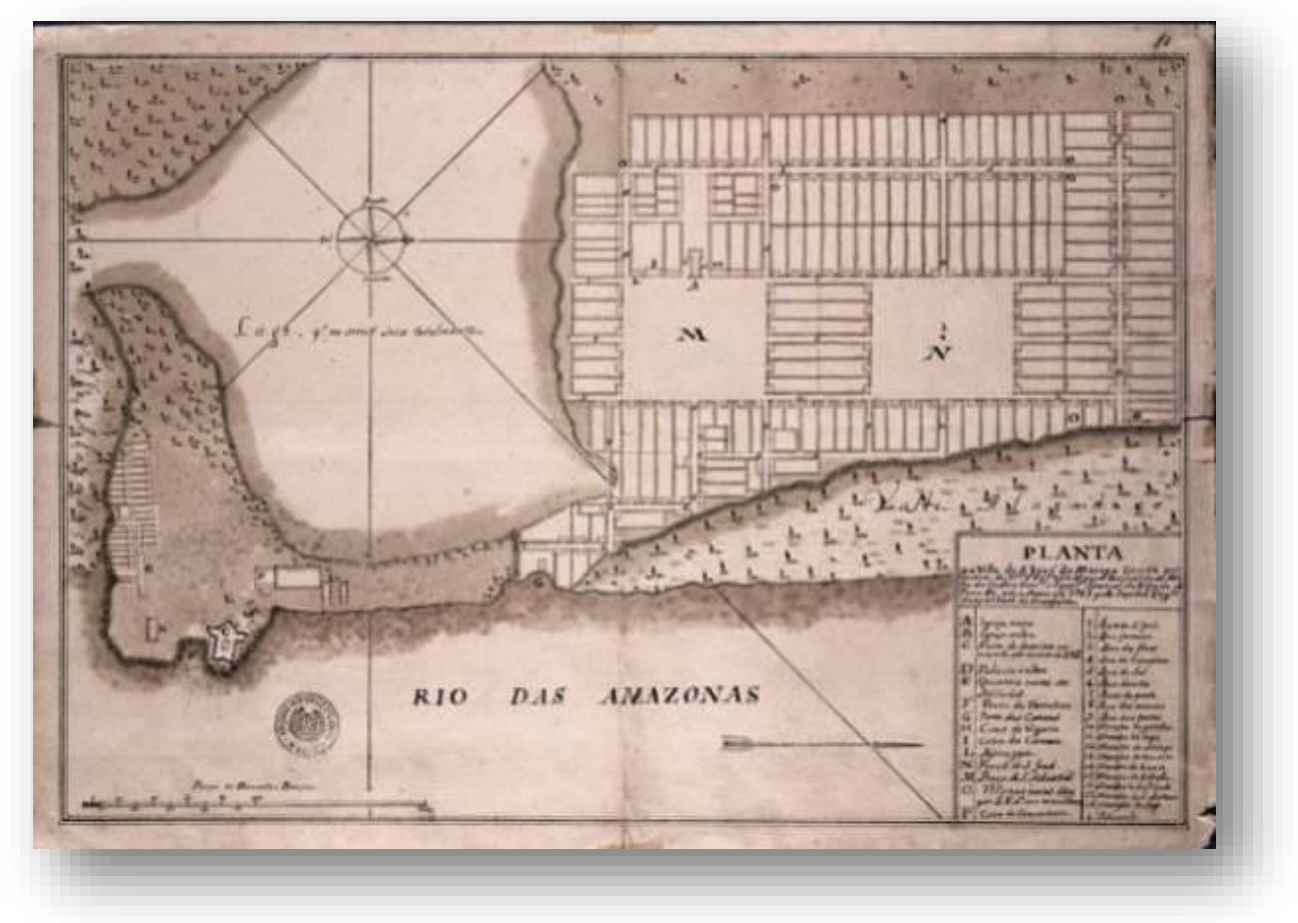

Imagem 1 - Mapa da Vila de São José de Macapá. Fonte: Arquivo Histórico do Exército - AHEX.

No mapa do traçado urbano da Vila de São José de Macapá, podemos identificar ruas e lotes regulares, além de duas grandes praças, a São Sebastião ( $M$ - hoje Veiga Cabral) e a São João (N - hoje Barão do Rio Branco). As únicas construções remanescentes desta época são a Igreja São José de Macapá (imagem 2) e a Fortaleza (imagem 3), pois a maioria das residências eram feitas de taipa, não resistindo à ação do tempo (LUNA, 2017). A Igreja de São José de 
Macapá, inaugurada no dia 06 de março de 1761, é o monumento mais antigo da cidade².

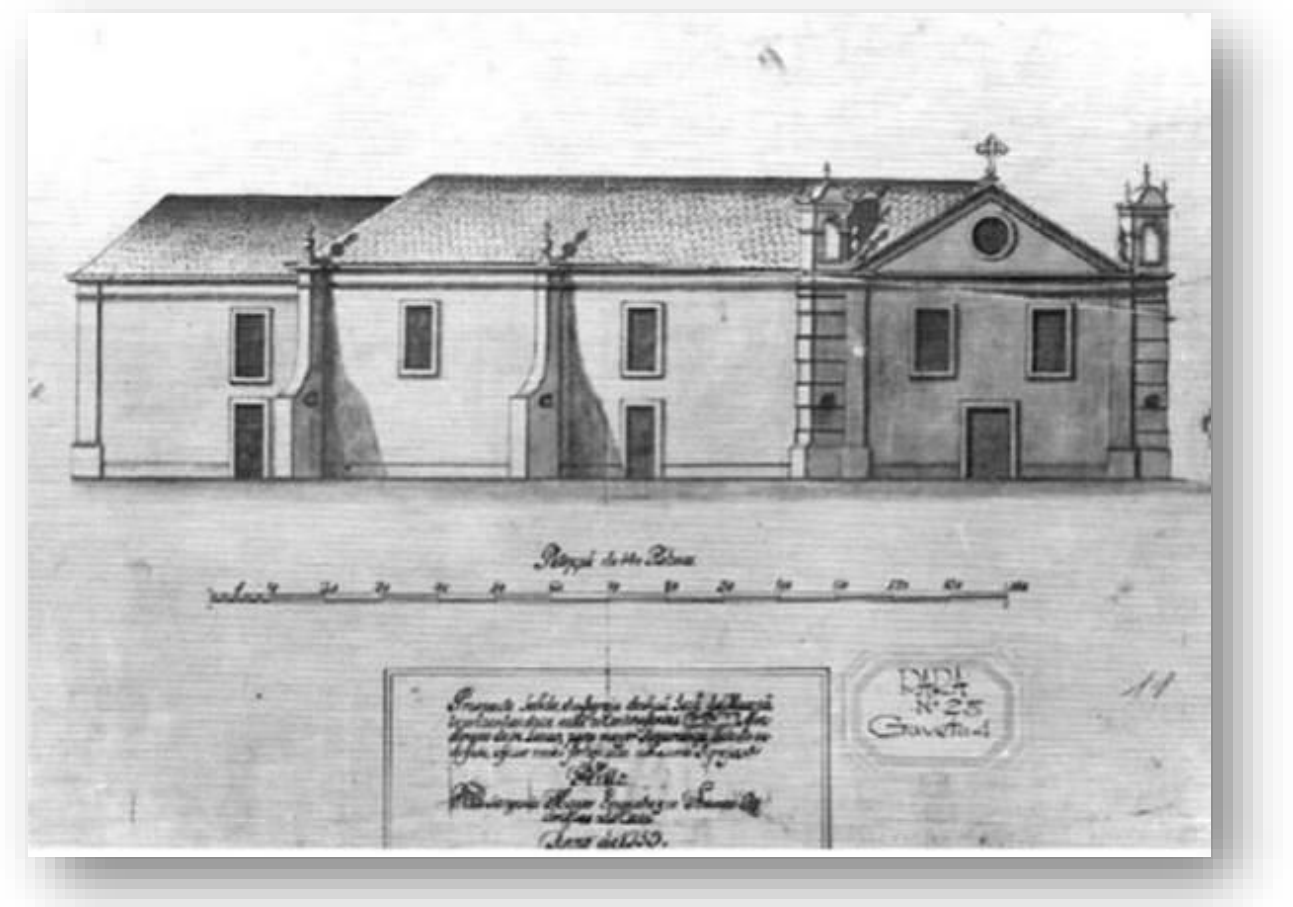

Imagem 2: Desenho original da Igreja de São José de Macapá, projetada pelo sargento major engenheiro Tomás Rodrigues da Costa, ano de 1759.Fonte: Araújo, 1998, p.178.

A construção da Fortaleza de São José de Macapá deu-se de 1764 a 1782. Segundo Canto (2017), ela serviu para marcar o território da conquista lusitana na Amazônia, e com isso mostrar o seu poder bélico para amedrontar possíveis invasores.Apesar de nunca ter sido efetivamente utilizada em um confronto, ela cumpriu com a sua missão de resguardar a entrada do rio Amazonas.

${ }^{2}$ Fonte: https://biblioteca.ibge.gov.br/biblioteca-catalogo.html?id=440387\&view=detalhes 


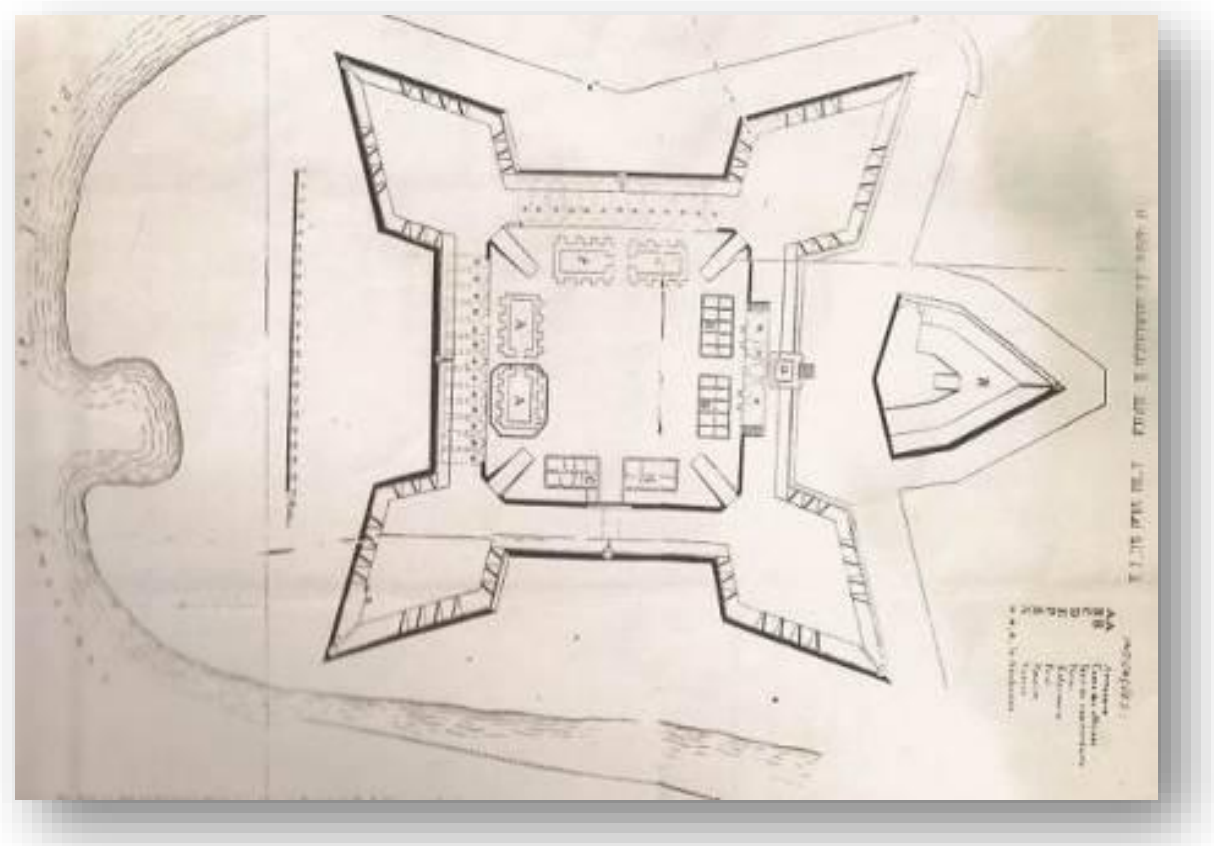

Imagem 3: Planta Baixa da Fortaleza de São José de Macapá.

Fonte: http://casteloroger.blogspot.com/search/label/Patrim $\% \mathrm{C} 3 \%$ B 4 nios $\% 20 \mathrm{do} \% 20 \mathrm{Amap} \% \mathrm{C} 3 \% \mathrm{~A} 1$ ? updated-max= 2011-04-26T04:26:00-07:00\&max-results=20\&start=36\&by-date=false.

Durante o século XIX, a região fazia parte da Província do Grão-Pará, conforme nos mostra a imagem 4, que se estendia pela região hoje formada pelos Estados do Pará, Amapá, Roraima e Amazonas.

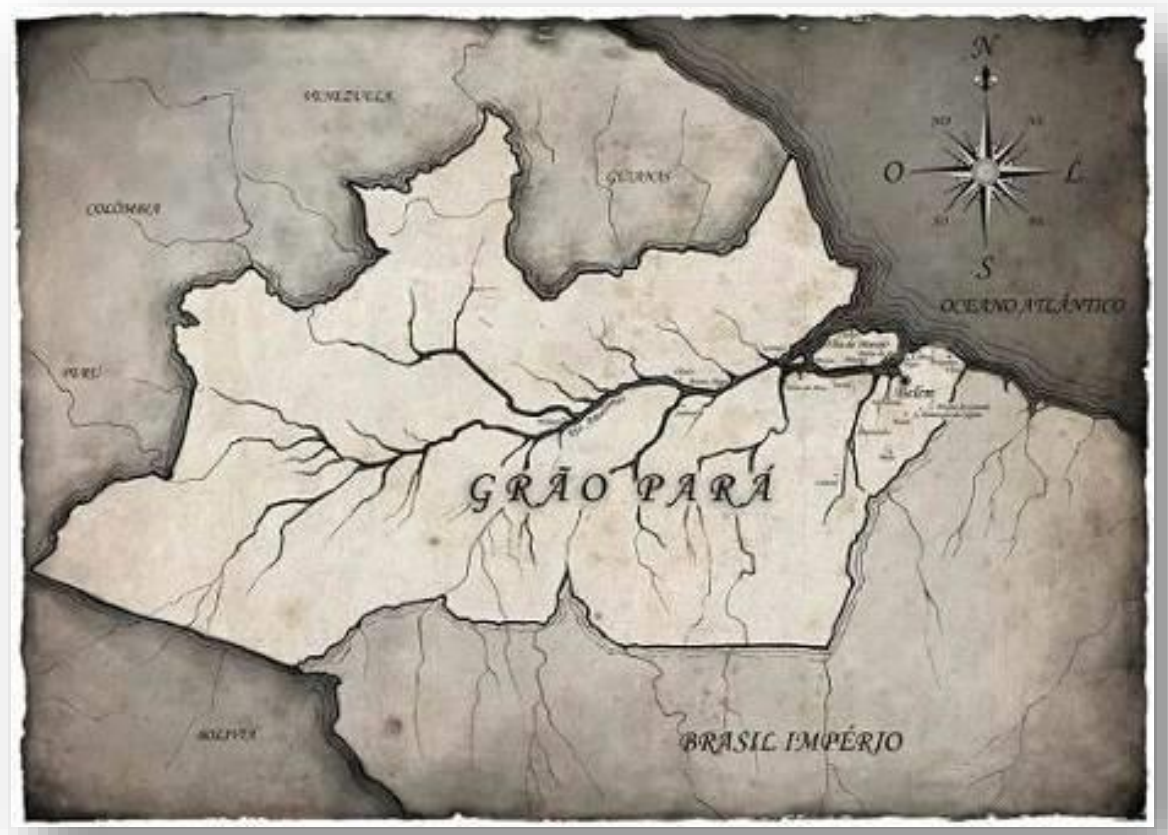

Imagem 4: Província do Grão-Pará.

Fonte: http://pjpontes.blogspot.com

PRACS: Revista Eletrônica de Humanidades do Curso de Ciências Sociais da UNIFAP 
$\mathrm{Na}$ época, seus moradores demonstravam insatisfação com a falta de atenção à região, esquecida pelo poder central. Os moradores de Macapá redigiram o Projeto Pinsônia, solicitando a transformação da região em uma província independente (SILVA, 2017). O projeto, entretanto, nunca retornou com um parecer. O Projeto Pinsônia é um projeto de lei da autoria de Cândido Mendes de Almeida ${ }^{3}$, submetido na Câmara dos Deputados no dia Primeiro de Julho de 1853, para a criação de uma província na fronteira do extremo norte do Brasil, tendo Macapá como sua capital. No mapa da imagem 5 verificamos que a Província de Pinsônia também englobava municípios como Óbidos, Alenquer, Faro, Outeiro e Almerim, que ainda hoje fazem parte do Estado do Pará.

Segundo Luna (2017), a mudança do status de vila para cidade em 1856 foi somente uma forma de apaziguar os ânimos da população, que já demandava por melhorias há muitos anos. No final do Império a região recebeu uma considerável leva de imigrantes, vindo majoritariamente do Ceará em direção à Amazônia. Grande parte dessa imigração se deu devido à grande seca do Nordeste de 1874 a 1879. Vieram muitos trabalhadores braçais, mas também fazendeiros e comerciantes, que pretendiam investir na região Norte, atraídos pelo ouro e pelos seringais. Nessa época chegaram os coronéis João Franklin Távora, Arlindo Eduardo Correa e Coriolano Finêas Jucá, trazendo seus homens para trabalharem como agricultores e capatazes, e outros como criadores de gado na condição de meeiros (LUNA, 2017).

No final do Império, o ouro, o criatório e terras devolutas levaram a região do norte do Pará a ser controlada por coronéis agropecuaristas e políticos (BARBOSA, 1997).Nas três primeiras décadas do século XX, a cidade de Macapá era uma sociedade controlada por forte relação de poder sob as ordens dos coronéis da Guarda Nacional.

Durante o ciclo da borracha, apesar de grandes regiões hoje correspondentes ao estado do Amapá, como o Jari, Mazagão e Amapá terem sido transformadas em áreas de extração de borracha, Macapá não se beneficiou economicamente, pois os comerciantes locais tinham que negociar e transportar o produto via porto de Belém. Essa foi a época áurea da cidade de Belém, na qual passou por grandes mudanças urbanas, e tornou-se conhecida como sua Belle Époque ${ }^{4}$, de acordo com Luna (2017). No entanto, as melhorias não se estenderam às regiões produtoras de látex.

Segundo Luna (2017), Macapá contava com maioria da população de afro descendentes, que habitavam nas terras altas da cidade, nos fundos da Igreja Matriz, área chamada de formigueiro, devido ao seu grande adensamento, e na Vila Santa Engrácia, pertencente ao Coronel José Serafim Gomes, na Praça São João, hoje Praça Barão do Rio Branco. A população branca habitava nos casarões. Tratava-se da elite administrativa da cidade, como intendente, delegado, oficial da comarca, curador de órfãos, coletores municipais e federais, padres, coronéis, professores e alguns comerciantes.

No início do século XX, Macapá sofreu uma pequena "europeização" com a chegada do Padre Júlio Maria Lombaerde. O sacerdote surgiu na cidade em 1913, com a responsabilidade da evangelização da população. De origem belga, o eclesiástico nunca concordou com os rituais afros existentes na região, tornando-se a sua principal querela com os habitantes locais.

\footnotetext{
${ }^{3}$ Cândido Mendes de Almeida (1818-1881), maranhense, foi advogado, deputado pelo Estado do Maranhão por cinco legislaturas e senador do Império. Fonte: www.cartaforense.com.br em 22 de outubro de 2018.

${ }^{4}$ A Belle Époque é uma conceituação para referir aos processos de modernização em algumas cidades brasileiras, remetendo à reforma da cidade de Paris planejada pelo Barão de Haussmann e a emergência de novos padrões de sociabilidade.
} 
Após embates, o sacerdote percebeu que a melhor forma de se aproximar da população seria através da ajuda à saúde. Sendo assim, acercou-se dos enfermos, portanto além dos medicamentos, a palavra de Deus. Outro viés de aproximação foi a educação,ocupando o cargo de diretor da escola municipal e, com o apoio financeiro de um comerciante local, fundou uma escola infantil, um internato feminino e implantou um pequeno teatro (BARBOSA, 1997). Ele conseguiu levar para Macapá a Congregação das Irmãs e Filhos do Coração Imaculado de Maria, com o intuito de produzir pessoal qualificado com a missão de educar e evangelizar. O sacerdote também trouxe da França um projetor de filmes SUPER8 em que exibia filmes religiosos e educativos. Com ele surgiu o primeiro cinema da cidade, o Cine Olímpia. Ele deixou Macapá em 1923.

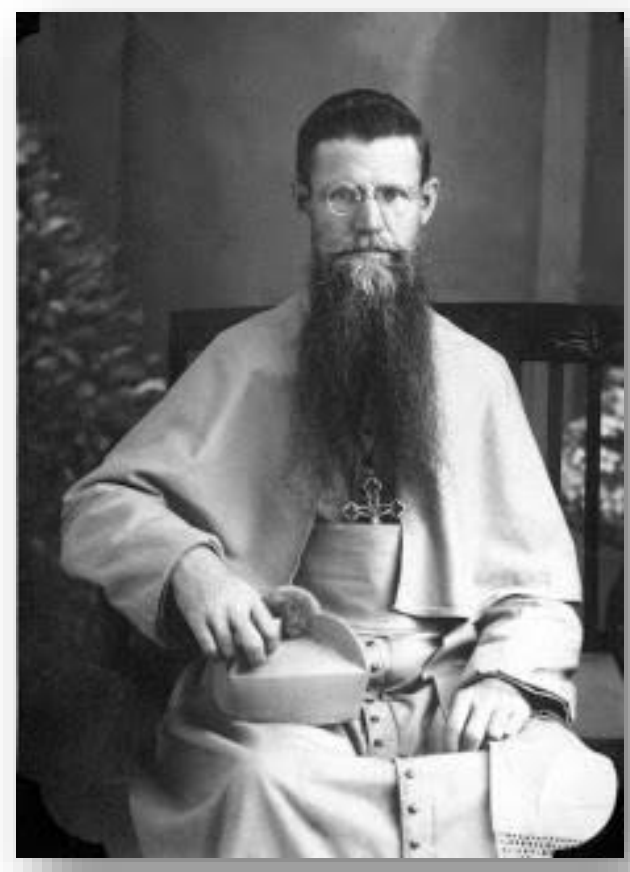

Imagem 6: Padre Júlio Maria Lombaerde.

Fonte: http://www.nossasenhoradasalegrias.com.br/

\section{O PROCESSO DE CRIAÇÃO DO TERRITÓRIO FEDERAL DO AMAPÁ}

A primeira solicitação de transformação do Amapá em Território Nacional se deu no ano de 1920. Foi um pedido feito ao então Presidente Epitácio Pessoa pela população local, devido ao descaso do governo paraense em relação à região (SILVA, 2017).

No ano de 1933, houve a elaboração de um plano para a criação de Territórios Federais por Everardo Adolpho Backheuser (SILVA, 2017). Segundo Martins (2001), sua proposta era dividir o país em paralelos e meridianos, transformando a federação em 64 unidades, agrupados em 16 estados e 6 territórios. O Território do Amapá teria fronteira delimitada até o Rio Paru (atualmente no estado do Pará) e sede em Almeirim. A escolha desta cidade como capital deve-se ao poder do coronel José Julio de Andrade, dono de grande área dos arredores, com produção de borracha, balata e castanha.

Efetivamente, o Território Federal do Amapá foi criado no dia 13 de setembro de 1943, 
através do Decreto-lei n 5.812, assinado pelo Presidente Getúlio Vargas, em que a região foi desmembrada do estado do Pará, com a intenção de promover o desenvolvimento econômico da região. ${ }^{5}$ Há mais de uma década já se sabia da existência de jazidas de outro na região de Cassiporé, e com a descoberta do manganês no Amapá, este foi desmembrado do Estado do Pará e transformado em Território Nacional, sob o controle do governo federal (MARQUES, 2009).

Durante o século XX, o manganês foi bastante empregado na indústria siderúrgica. De acordo com Monteiro (2003), desde o fim da Primeira Guerra, em função da crescente demanda mundial, o preço do manganês aumentou. Com o fim da Segunda Guerra Mundial, o manganês ampliou a sua importância estratégica, pois, com a "guerra fria", a antiga União Soviética, detentora das maiores reservas mundiais, suspendeu a sua exportação para países capitalistas. A exploração de manganês no Amapá foi a primeira experiência de mineração industrial na Amazônia.

Ela foi realizada pela ICOMI, empresa de capital 49\% norte-americano, que chegou a ser a quarta maior exportadora de manganês do mundo nos anos 1950. Conforme Monteiro (2003), noventa e nove por cento do minério era exportado para os Estados Unidos da América. Em princípio, a cidade escolhida para ser a capital do novo território foi Amapá, devido à sua localização central no território, próxima à Base Aérea Americana e ao fato de que nela se concentrava a elite pecuarista da região (PORTO, 2014).

Porém, Janary Nunes decidiu instalar a sua capital na cidade de Macapá, devido à proximidade com o Rio Amazonas e com a cidade de Belém, capital do Pará, facilitando a circulação de bens e mercadorias, e retirando o poder das mãos da elite amaparina local, para seu maior controle.

Os governadores dos Territórios eram escolhidos diretamente pelo presidente da República, Getúlio Vargas. O primeiro governador do território foi o militar Janary Gentil Nunes. Janary nasceu em Alenquer, Estado do Pará, em 1912. A escolha do capitão Janary Gentil Nunes foi devido ao seu conhecimento da região - tendo servido no Oiapoque e em Belém (LUNA, 2017). Como governador, estruturou a capital político e administrativamente, e foi o responsável pela construção de edificações fundamentais na cidade, como escolas, hospitais e iniciou o ordenamento urbanístico da cidade, com conjuntos residenciais (NUNES, 1946). Permaneceu no governo por quase doze anos, o que o permitiu dar continuidade ao seu projeto, ao contrário dos demais territórios, que tiveram grande rotatividade de gestores.

Janary Nunes levou à Macapá mão-de-obra especializada para auxiliá-lo na implantação do território, como engenheiros, administradores e professores. Esses profissionais migraram, alguns sozinhos, outros com suas famílias, e formaram a base da classe alta e média da cidade da época, juntamente com os filhos da elite pecuária de Amapá (PORTO, 2014).

As mulheres, em sua maioria, ficaram responsáveis pelos cargos assistencialistas, como professoras, enfermeiras e domésticas. A classe trabalhadora foi formada principalmente com mão-de-obra de origem das ilhas paraenses dos arredores e nordestina, com migração acentuada de homens. Muitas vinham do interior da Amazônia, para trabalhar como

\footnotetext{
${ }^{5} \mathrm{O}$ país estava vivendo o Estado Novo, um período de ditadura, governado por Getúlio Vargas. Era um governo de caráter nacionalista e desenvolvimentista. No contexto da Segunda Guerra Mundial, com a coalisão fascista obtendo várias vitórias, urgia a necessidade de defesa das fronteiras nacionais. Vale lembrar que a França foi ocupada pela Alemanha durante os anos 1940 a 1944 e, por consequência, que a Guiana Francesa, com uma fronteira de setecentos e trinta quilômetros com a costa brasileira, estava também sob ocupação nazista (PORTO, 2014)
} 
domésticas. De acordo com Sidney Lobato (2009), em 1943, Macapá era a $49^{\text {a }}$ cidade da Amazônia em população. No fim do governo Janary, em 1955, ela era a quarta cidade da Amazônia em número de habitantes. $O$ aumento populacional e as transformações empreendidas mudaram a feição da cidade. Mas em que consiste esta nova feição? A análise das fotografias da época nos auxiliam a entender um pouco melhor a transformação sofrida pela cidade.

\section{A FOTOGRAFIA COMO INSTRUMENTO DE ANÁLISE URBANA DA CIDADE DE MACAPÁ}

Seja pelo senso comum, seja pela sutileza de algumas definições, dependendo do olhar, dos objetivos e de qual informação se está buscando, uma fotografia pode se prestar para vários fins. Alguns pensadores da fotografia, como Flusser ${ }^{6}$, Fabris $^{7}$, e Soulages ${ }^{8}$, questionam o uso da fotografia como registro do real. É consenso na historiografia crítica da fotografia que a imagem fotografada tem grande contribuição do fotógrafo. Porém, não se pode questionar que ela é produzida a partir de algo que já existiu. Por isso até hoje, a fotografia ainda é empregada para comprovações de sinistros, registros policiais, etc.

Como fundamentação do uso da fotografia para a análise da transformação da cidade durante o período janarista (1944-1956), nos apoiamos em Boris Kossoy (1989). O autor, em seu livro Fotografia e História, esclarece que apesar do significativo aumento de dissertações e teses que trabalham com fotografias na década de 1990, o documento fotográfico ainda é tratado com descaso e o preconceito no Brasil. Ele afirma que existe um aprisionamento multissecular à tradição escrita como forma de transmissão do saber, e que a fotografia ainda não alcançou plenamente o status de documento. Ele cita o depoimento de Carney E. S. Gavin:

Paradoxalmente, os documentos fotográficos, apesar de sua legendária superioridade em relação aos registros verbais, ainda hoje frequentemente escapam da malha fina da erudição. Os bibliotecários diligentemente preservam minúsculos fragmentos das notas de um escritor, curadores de arte guardam como tesouro até o mais inacabado esboço de um artista; no entanto muitos repositórios culturais contêm preciosas fotografias que jamais foram registradas nos inventários. (GAVIN, 1985, apud KOSSOY, 1989, 4 ed, p. 31)

Ele defende a necessidade de se tomar a palavra "documento" no sentido mais amplo, englobando documentos escritos, ilustrados, sonoros, visuais e outros. E afirma que as fontes fotográficas são uma possibilidade de investigação e descoberta que promete frutos quando há a sistematização de suas informações e o estabelecimento de metodologias adequadas de pesquisa e análise para a decifração de seus conteúdos e da realidade que os deu origem. A fotografia pode servir como documento histórico - com características de uma época ou como comprovante de determinado fato histórico, apresentando informações de uma técnica

${ }^{6}$ Filósofo nascido em Praga em 1920, Vilém Flusser escreveu em 1983 Für eine Philosophie der Fotographie, traduzido para o português com o título Filosofia da Caixa Preta em 1985. Faleceu em 1991.

7 Professora da ECA-USP, Annateresa Fabris tem vários livros publicados sobre fotografia, modernidade e pintura, como O Desafio do Olhar, publicado em dois volumes em 2011 e 2013.

${ }^{8}$ François Soulages é um crítico de arte francês contemporâneo especializado na estética da fotografia. Publicou em 1998 o livro Estética da Fotografia: Perda e Permanência, traduzido para o português em 2010. 
construtiva específica ou uma solução arquitetônica para tratar e resolver os espaços ou estratégias urbanísticas, e ser também uma expressão artística - pelo valor estético que o fotógrafo agregou ao registro fotográfico.

O autor também sustenta que, partir do conteúdo documental que contém, as fotografias que retratam diferentes aspectos da vida passada de um local são importantes para os estudos históricos existentes em diferentes áreas do saber e que elas podem ajudar a recuperar informações a respeito do espaço em questão.Portanto, as fotografias que tenham valor de documento são valorosas para pesquisas nas mais diversas áreas, como a arquitetura, o urbanismo, a antropologia, a etnologia, a arqueologia e outras, pois são uma oportunidade de resgate da memória visual de uma sociedade e do espaço por ela ocupada.

\section{TRÊS CONSTRUÇÕES DE SEUS IMPACTOS NA MODIFICAÇÃO ARQUITETÔNICA DA CIDADE: ALGUMAS MANIFESTAÇÕ̃ES FOTOGRÁFICAS DA NOVA CAPITAL AMAPAENSE}

Neste trabalho, trataremos das imagens referentes à três grandes construções realizadas na época em questão, obras que modificaram significativamente o cenário da cidade: o Macapá Hotel (1944), o Grupo Escolar Barão do Rio Branco (1946) e o Colégio Amapaense (1952).

A edificação mais fotografada no referido período é o Macapá Hotel, primeiro hotel construído na cidade. As margens do Rio Amazonas, sua morfologia chama a atenção até os dias atuais, pela inspiração no período colonial, como podemos observar nas imagens 7, 8, 9, 10 e 11. No primeiro andar contava com um amplo hall, salão de refeições para oitenta pessoas, salão de jogos e diversões, barbearia, perfumaria, engraxataria e bar, além de dependências de serviço e terraços com mosaicos. No segundo andar, possuía apartamentos de dois dormitórios e dezesseis quartos, os oito frontais com amplas varandas com vista para o Rio Amazonas, infraestrutura suficiente para uma cidade com mil e quinhentos habitantes, segundo o relatório de Janary Nunes para o Presidente da República, de $1944^{9}$. O neocolonial ${ }^{10}$ era um dos estilos consagrados na busca pela identidade nacional em vigor nos anos 1920, que logo viria a ser questionado em 1931 por Lucio Costa, mentor intelectual do Movimento Moderno no Brasil que defendeu a tradição colonial vinculada às formas e procedimentos contemporâneos $^{11}$. A construção do Macapá Hotel em 1944 em estilo neocolonial é, portanto, extemporânea, pois é bastante tardia, mesmo em relação às múltiplas forças ideológicas e aos variados princípios estéticos que fizeram parte do governo getulista do Estado Novo. ${ }^{12}$

\footnotetext{
${ }^{9}$ Fonte: https://hotelmacapa.com.br/hotel/

$10 \mathrm{O}$ neocolonial foi um movimento estético dos começos do século XX especialmente associado à arquitetura. O movimento se propunha a resgatar a arquitetura e motivos decorativos típicos da época colonial americana de origem ibérica e empregá-los na arquitetura contemporânea.

11 Ver COSTA, L. Registro de uma vivência. Rio de Janeiro: Empresa das Artes, 1995.

12 O Estado Novo se notabiliza por construir grandes edifícios públicos em estilo Arte Déco e Eclético, além da Arquitetura Moderna do consagrado MESp (1936-1943) e de outros.
} 


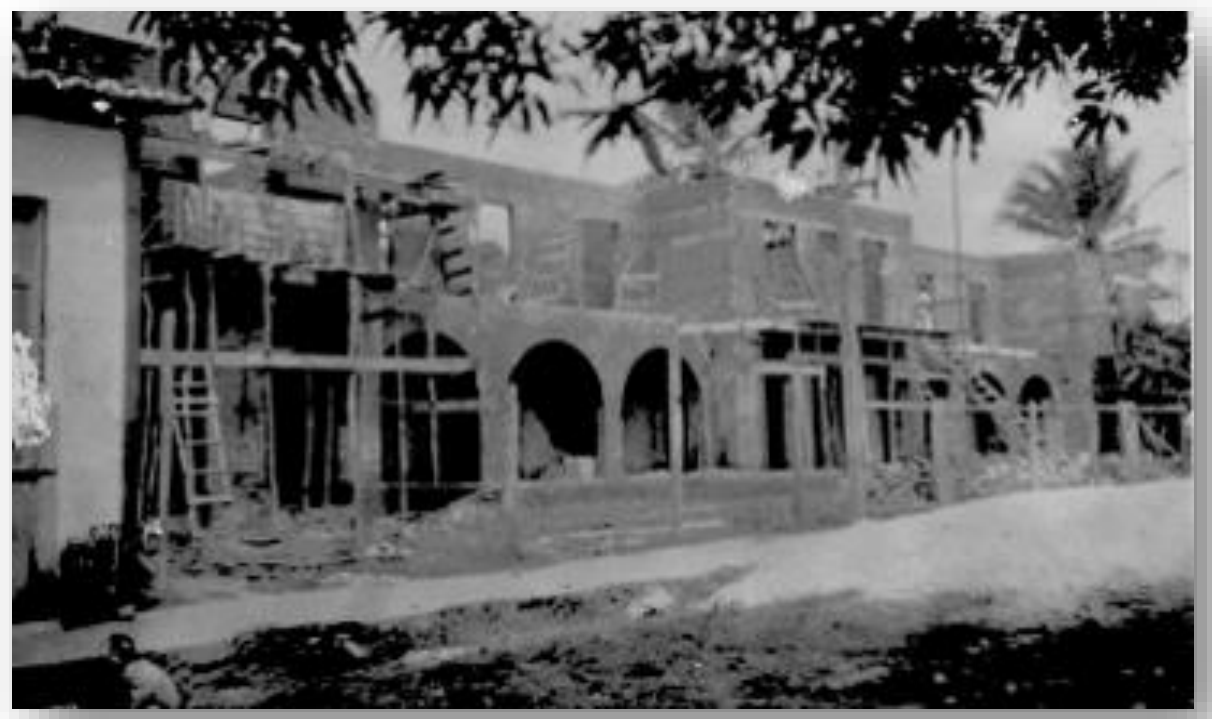

Imagem 7 - Construção do Macapá Hotel.

Acervo João Lázaro, 1944.

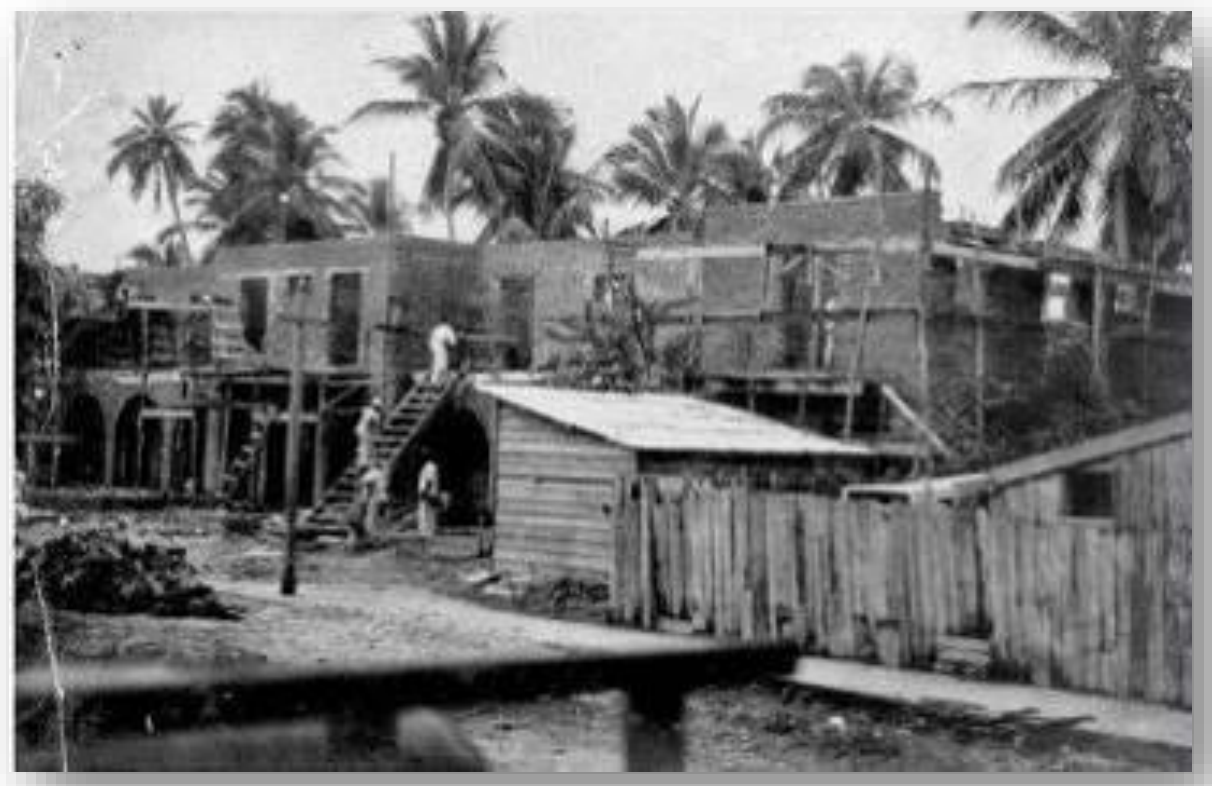

Imagem 8 - Construção do Macapá Hotel. Observar a precariedade do canteiro de obras e da vestimenta dos operários, esta última característica também de obras nas principais cidades do país.

Acervo de Juvenal Canto, 1944.

PRACS: Revista Eletrônica de Humanidades do Curso de Ciências Sociais da UNIFAP 


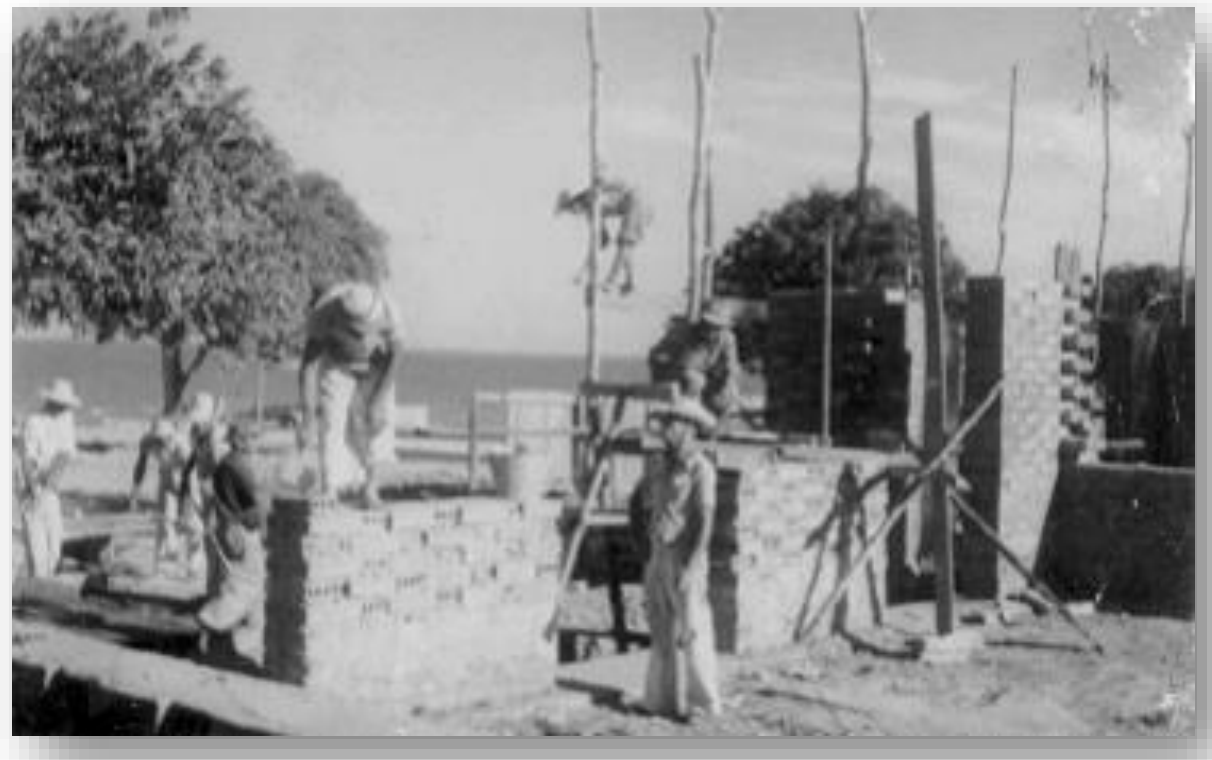

Imagem 9 - Grande Hotel de Macapá.

Acervo O Observador Econômico e Financeiro, 1945.

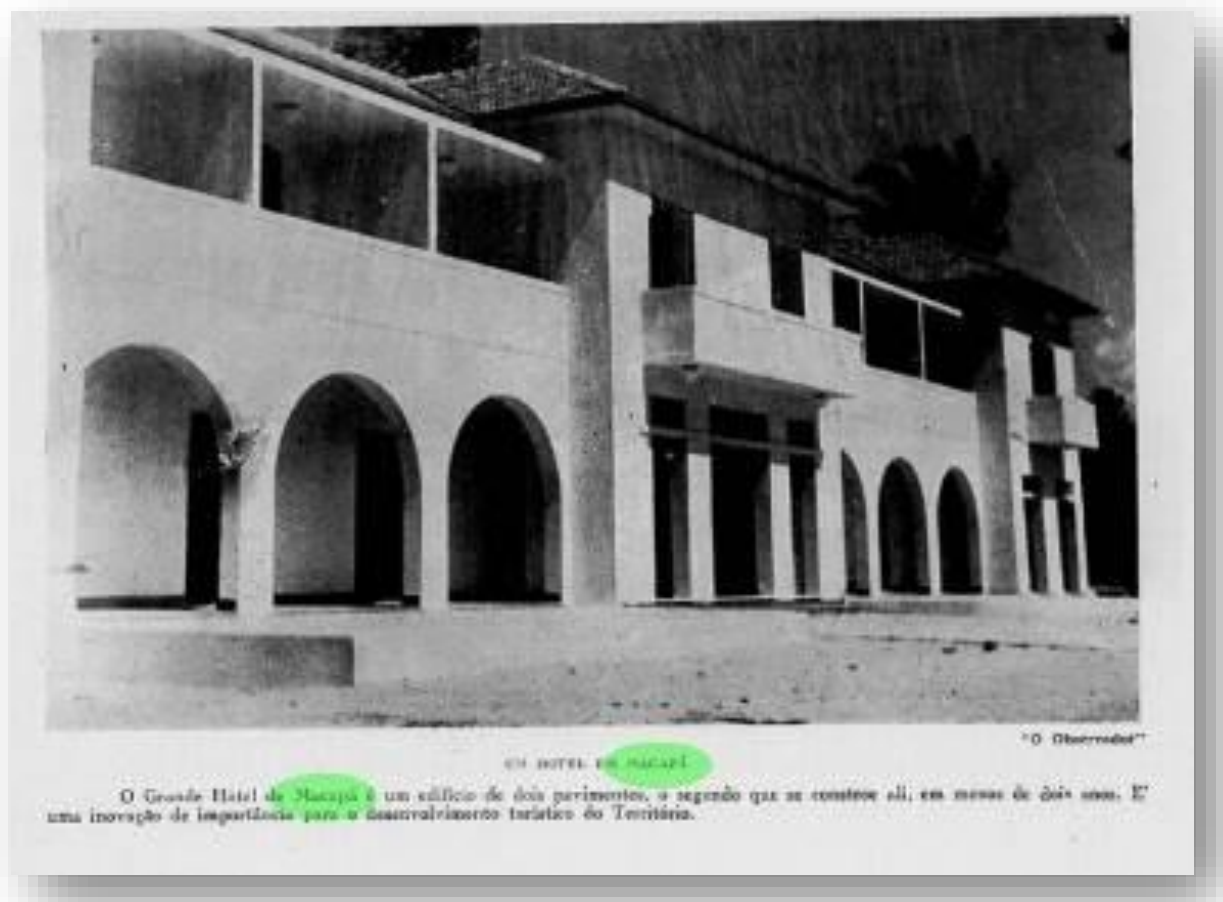

Imagem 10 - Grande Hotel de Macapá.

Acervo O Observador Econômico e Financeiro, 1945. 


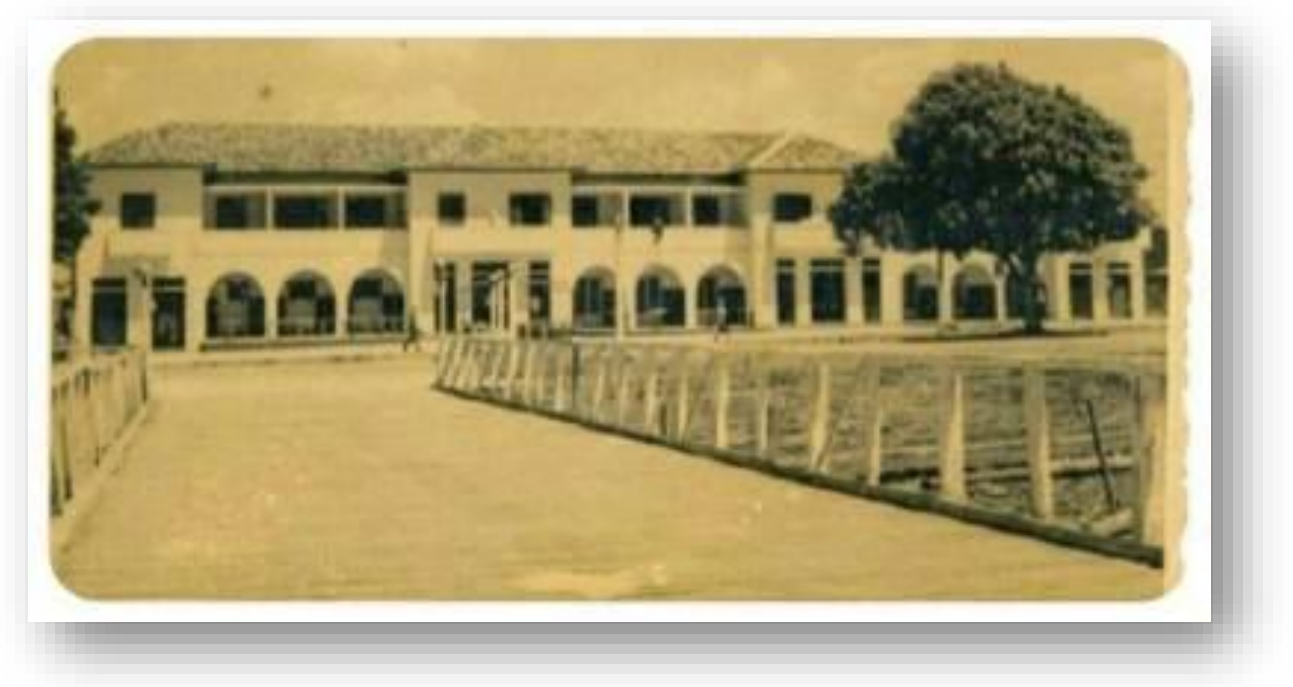

Imagem 11 - Construção do Macapá Hotel.

Acervo João Lázaro, 1945.

Sua edificação é icônica e imponente em relação às construções vizinhas, mesmo atualmente. A importância dada à edificação coaduna com sua importância social. O Macapá Hotel representa o lugar de chegada e de encontro da nova alta classe amapaense janarista, os funcionários, empreendedores e profissionais especializados que vieram povoar com suas famílias a nova capital, consagrando a sua modernidade e civilidade.

O Grupo Escolar Barão do Rio Branco foi a primeira escola em alvenaria da cidade, com doze salas de aula. Nas imagens 12 e 13, temos o projeto e a planta do edifício, e na imagem 14 a sua construção. Foi inaugurado em 1946, conforme a imagem 15, um dos primeiros prédios construídos no governo de Janary Nunes ${ }^{13}$. No relatório do governador Janary Gentil Nunes ao Presidente da República ${ }^{14}$, com informações sobre as ações executadas em seu primeiro ano de gestão, consta que, anteriormente à criação do TFA, quando ainda era parte do Estado do Pará, a região possuía somente sete escolas em funcionamento, três no município de Macapá, e oito professores trabalhando, quatro normalistas e quatro leigos.

13 Fonte: https://porta-retrato-ap.blogspot.com.br/2010/04/grupo-escolar-barao-do-rio-branco.html

14 O relatório foi redigido pelo governador Janary Gentil Nunes e sua equipe de gestão no final de 1944, para o então Presidente da República, Getúlio Vargas, e impresso publicado pela Imprensa Nacional, no Rio de Janeiro, em 1946. 


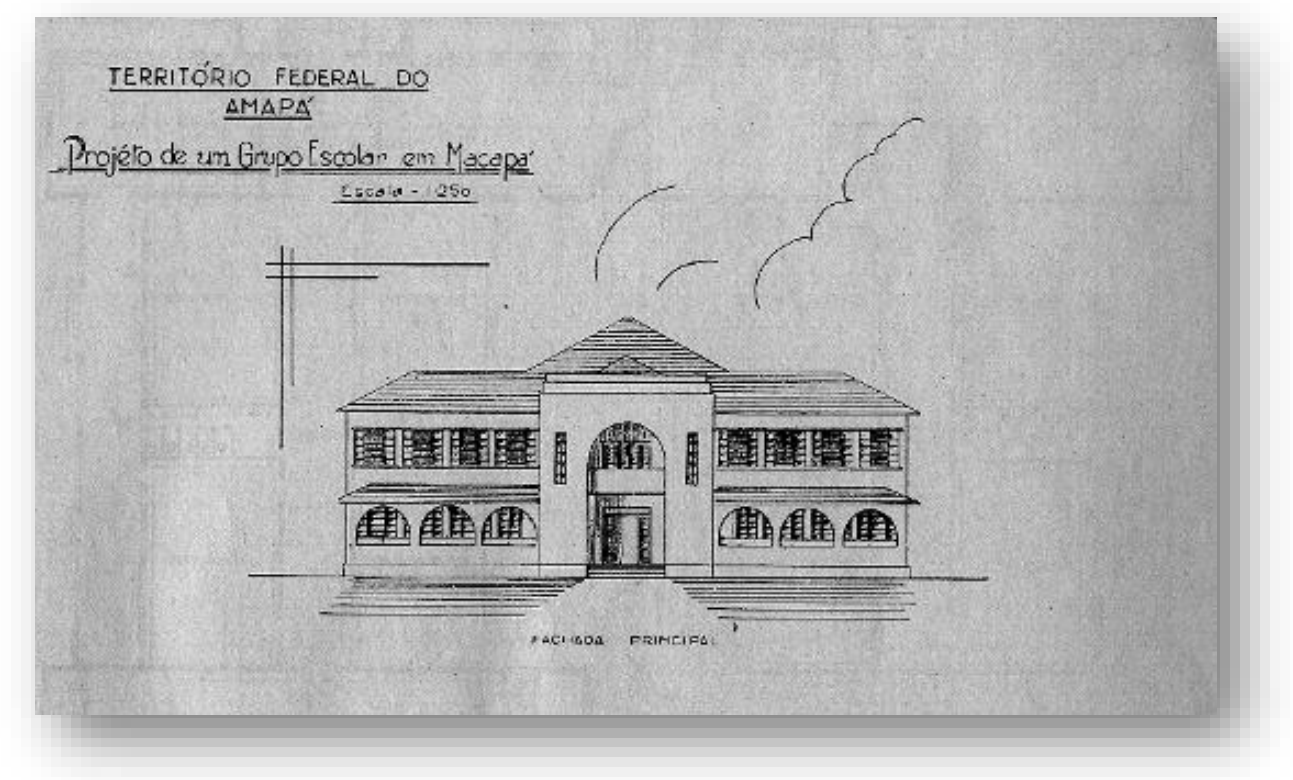

Imagem 12 - Projeto do grupo escolar.

Fonte: Relatório de Atividades do Governo do Território Federal do Amapá, 1944.

A região possuía somente ensino primário, a evasão escolar era altíssima e um teste aplicado, para se avaliar o nível escolar dos alunos, se mostrou desalentador. As escolas estavam em péssimas condições: funcionavam numa só sala, sem lavatório, sem vaso sanitário nem água filtrada, com número de carteiras insuficiente, quatro delas sem quadro negro, e quase nenhum material escolar. A construção do Grupo Escolar, com então 12 salas de aula, aporta a nova dimensão da cidade e a importância concedida à educação. A fachada do edifício com um arco central com pé direito duplo ${ }^{15}$ reitera a grandiosidade, e junto com as arcadas do primeiro pavimento, associam-no à tradição colonial. A gramática Arte Déco do segundo pavimento instaura uma ideia de modernização, com a sugestão da industrialização da construção nas esquadrias seriais.

${ }_{15} \mathrm{Na}$ história da arquitetura denominado de ordem colossal 


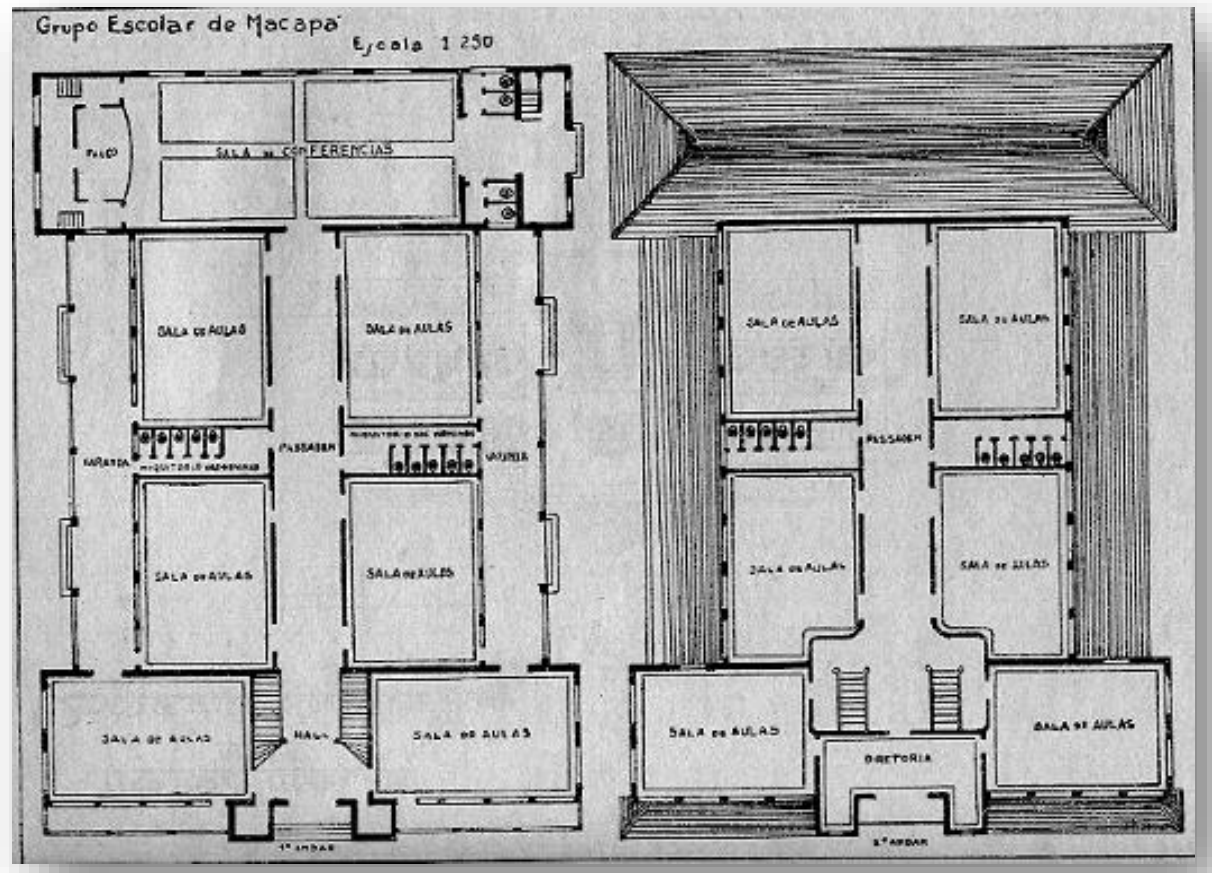

Imagem 13 - Planta do grupo escolar.

Fonte: Relatório de Atividades do Governo do Território Federal do Amapá, 1944.

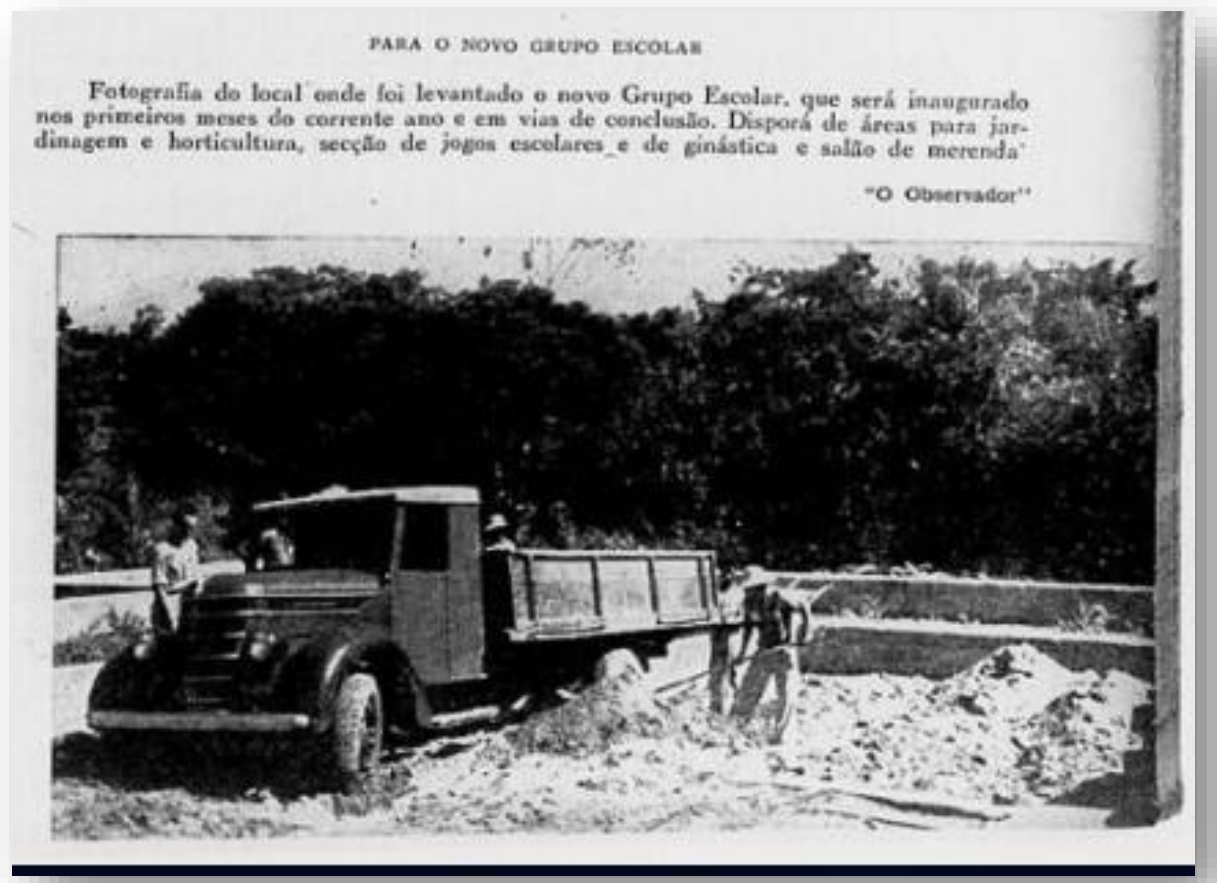

Imagem 14 - Construção de novo grupo escolar.

Acervo O Observador Econômico e Financeiro, 1945. 


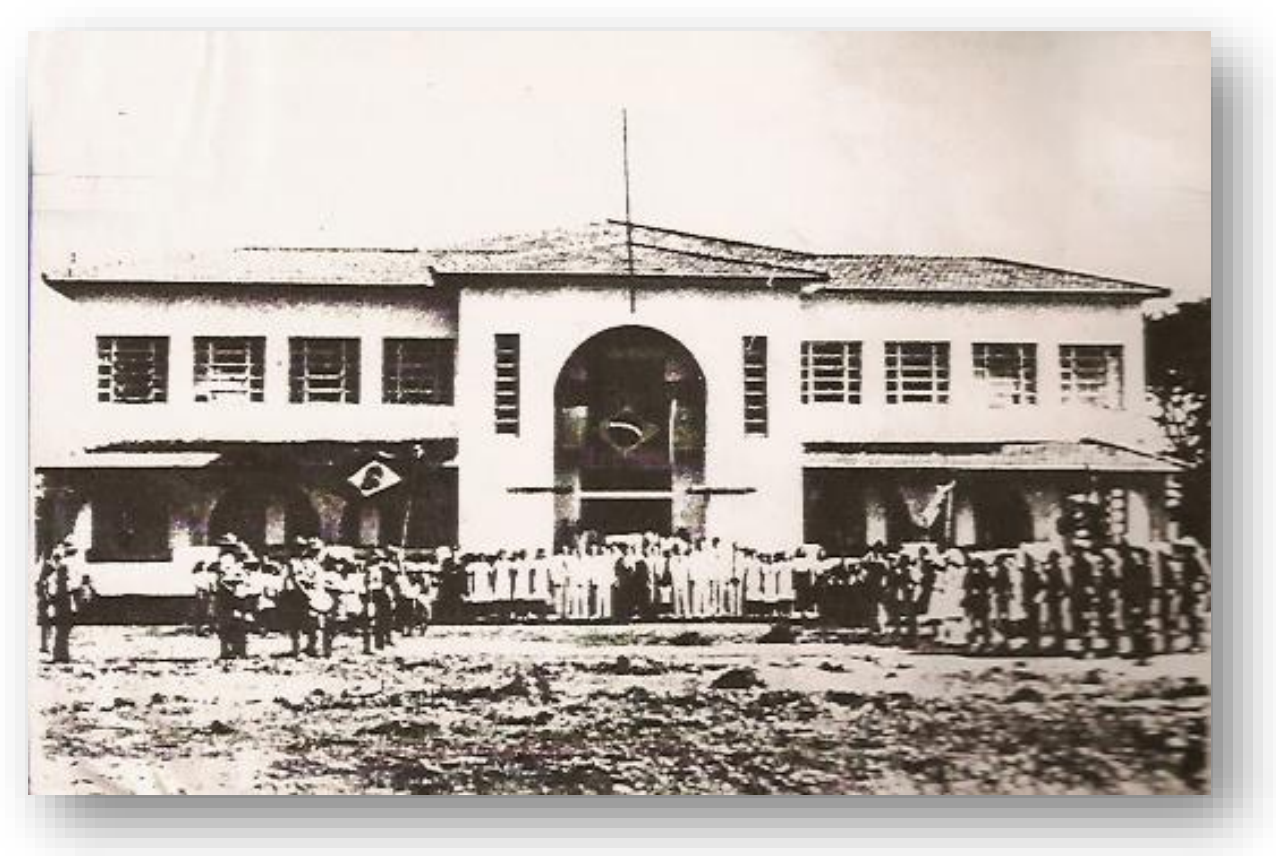

Imagem 15 - Inauguração do Grupo Escolar Barão do Rio Branco, 1946.

Fonte: https://porta-retrato-ap.blogspot.com/2010/04/grupo-escolar-barao-do-rio-branco.html

O Colégio Amapaense iniciou suas atividades em 1952, sendo o primeiro colégio com ensino médio na cidade. É um dos primeiros edifícios modernistas da cidade, conforme podemos verificar nas imagens 16, 17 e 18. Primeiramente, funcionava com nove salas de aula, nos três turnos: matutino, vespertino e noturno. Era na época o prédio mais alto do Território do Amapá, competindo apenas com o antigo Pensionato São José, localizado atrás da Igreja de São José16. A elevação sobre pilotis, o volume destacado da circulação externa horizontal remete à arquitetura moderna empregada na capital do país na época, o Rio de Janeiro, reconhecida historiograficamente como Escola Carioca ${ }^{17}$. Desta, destacam-se a leveza do volume e o superdimensionamento característico de algumas obras estatais modernas na capital federal na época.

\footnotetext{
${ }^{16}$ Fonte: https://porta-retrato-ap.blogspot.com.br/2010/04/colegio-amapaense.html

${ }^{17}$ Escola Carioca é um termo usado para identificar a arquitetura produzida entre os anos 1940 e 1950 por um grupo de arquitetos radicados no Rio de Janeiro, como Lúcio Costa e Oscar Niemeyer. Como exemplos, temos os edifícios do Ministério de Educação e Saúde (atual Edifício Gustavo Capanema), o Museu de Arte Moderna do Rio de Janeiro, e o Conjunto Residencial Prefeito Mendes de Moraes.
} 


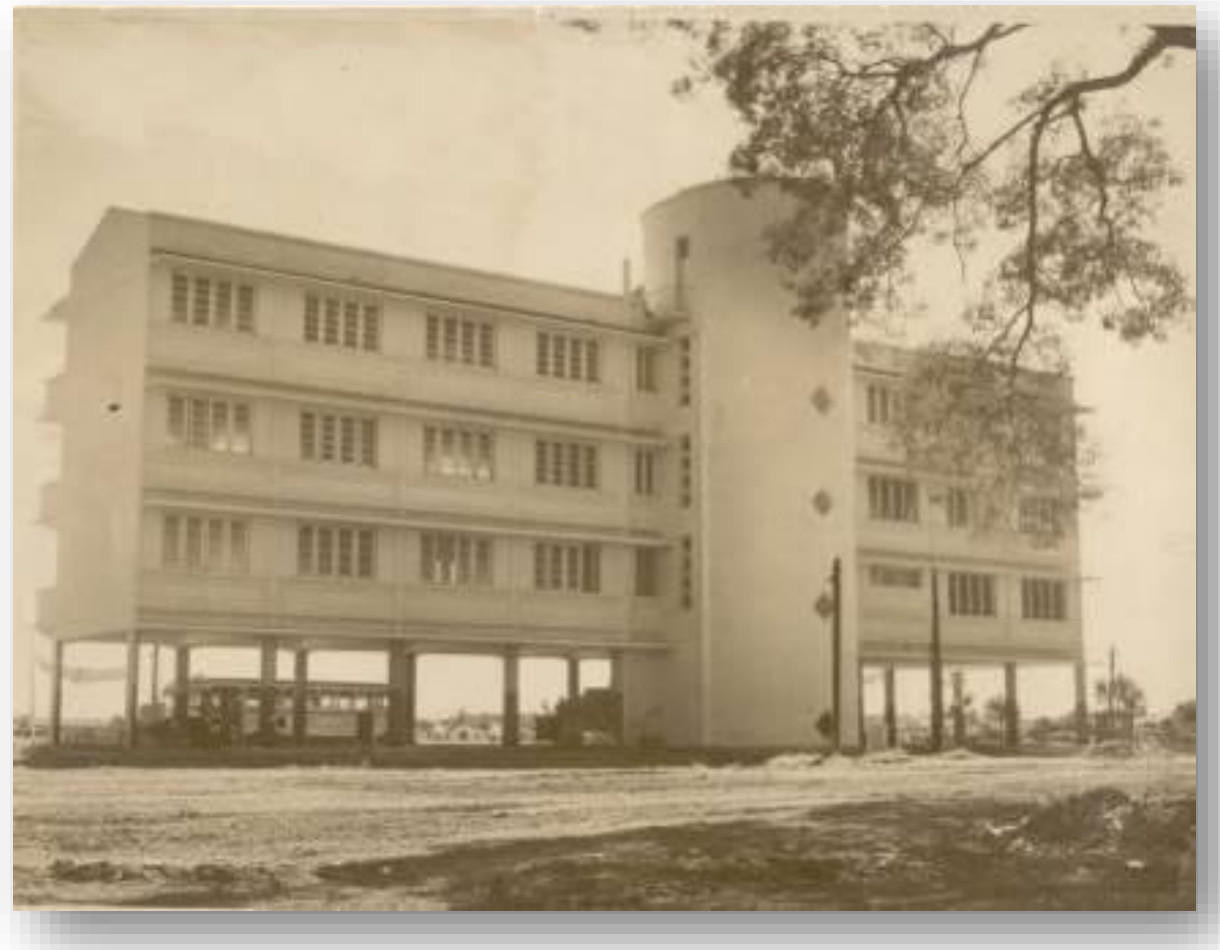

Imagem 16 - Colégio Amapaense.

Acervo Jornal Diário do Amapá, 1954.

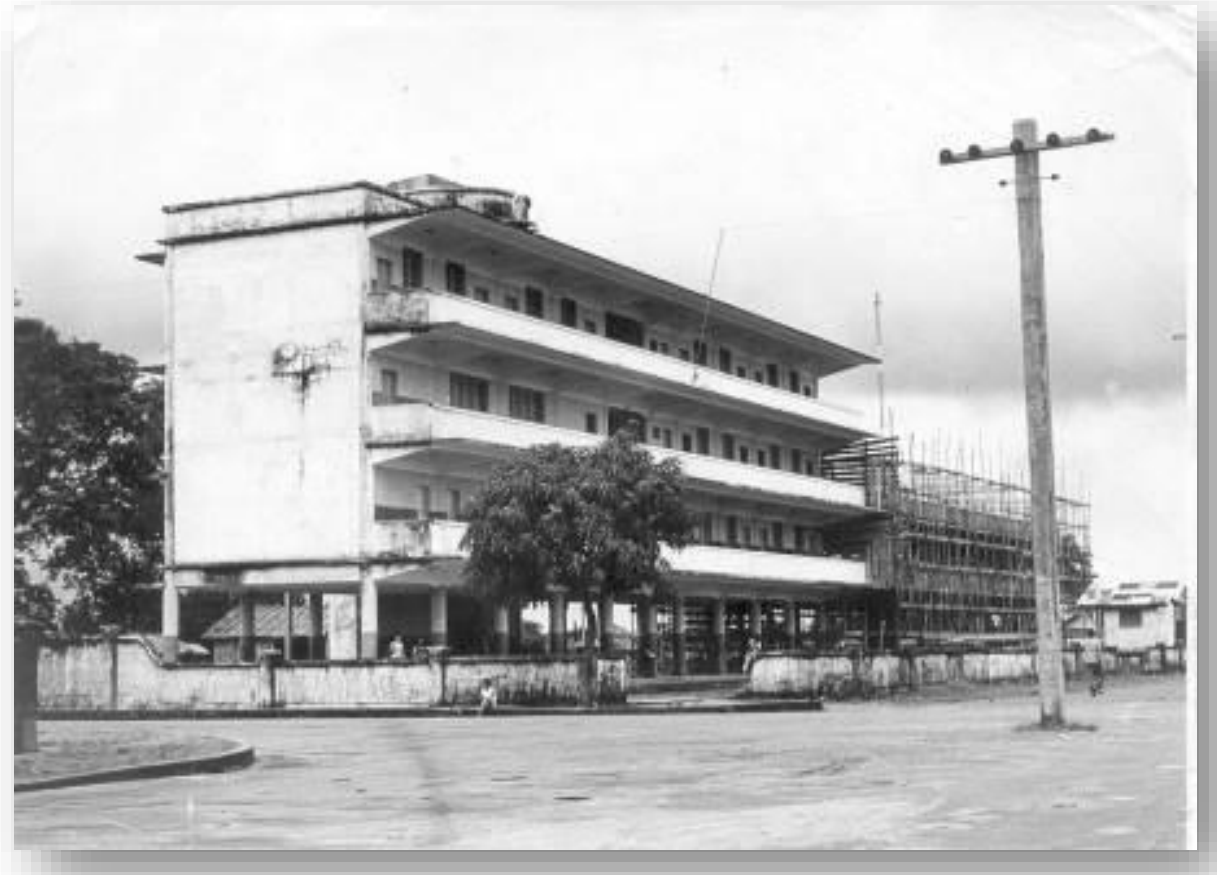

Imagem 17 - Construção do Colégio Amapaense.

Acervo João Lázaro, anos 50.

PRACS: Revista Eletrônica de Humanidades do Curso de Ciências Sociais da UNIFAP 


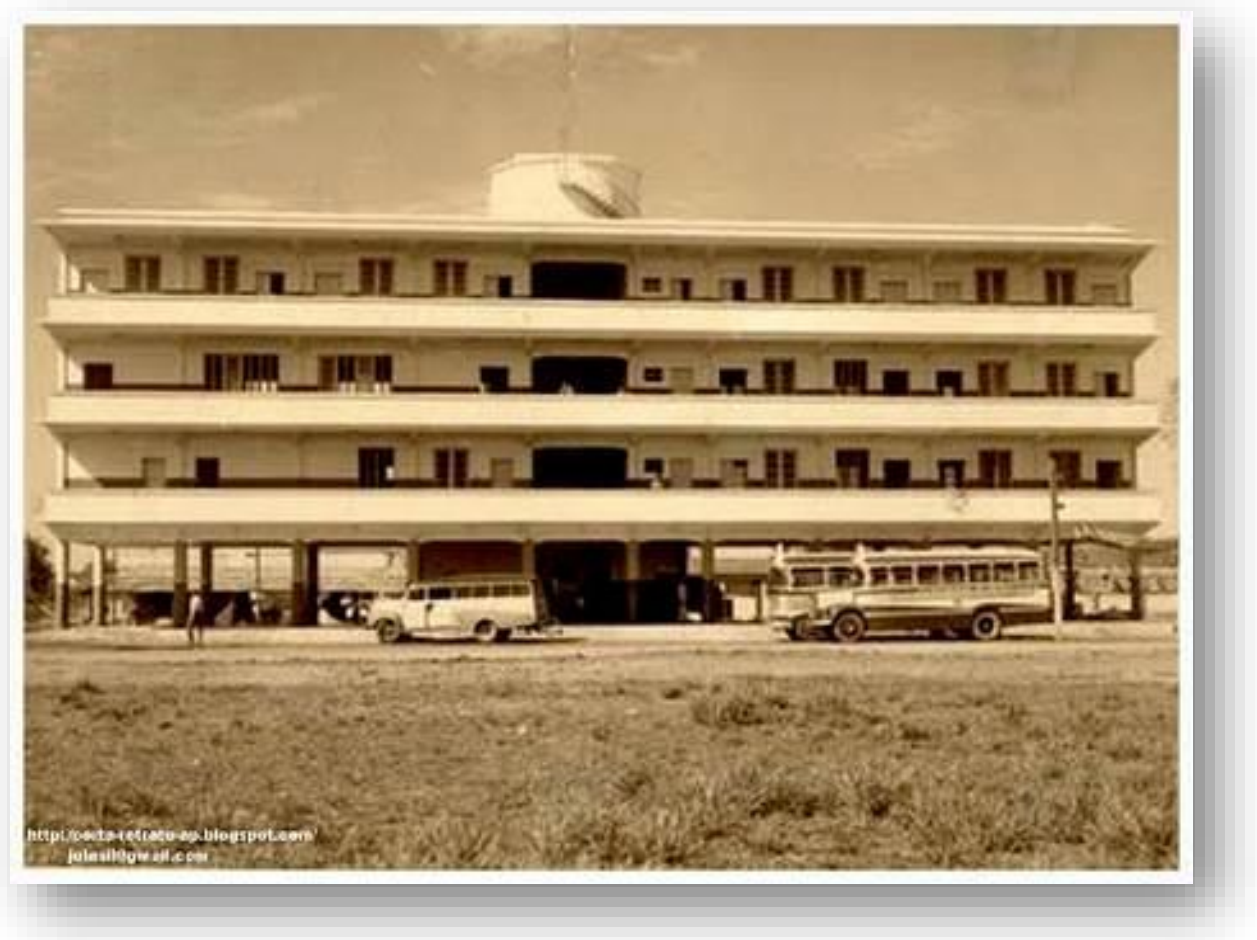

Imagem 18 - Colégio Amapaense.

Acervo João Lázaro, 1955.

O Colégio Amapaense é um marco para a cidade de Macapá, sob vários aspectos: tanto pelo pioneirismo na oferta do ensino ginasial na região; quanto, pelo aspecto da paisagem, pelo destaque que tinha entre todos os edifícios da capital na época, pelas suas dimensões e pelo seu estilo arquitetônico.

\section{CONSIDERAÇÕES FINAIS}

A gênese das transformações na paisagem da cidade de Macapá é decorrente da transferência de capital da sede do Município de Amapá para Macapá, e os registros fotográficos de edifícios do primeiro decênio da nova capital são intencionalmente institucionais. No âmbito deste artigo, optamos pela análise dessas edificações emblemáticas de dois setores: educacional e hoteleiro, por suas representações materiais e imateriais.

Dois pontos marcam estas construções: o primeiro concerne às suas funções na nova capital; e o segundo, aos conceitos arquitetônicos e novos materiais de construção adotados. Com elas, a cidade de Macapá marca o início de sua nova fase no território,apontando novas posturas arquitetônicas e novos conceitos urbanísticos.

No contexto urbanístico, as obras acima citadas diferiam de quase todas as edificações térreas de madeira existentes na cidade antes da criação do território, com exceção da Igreja São José de Macapá e a Fortaleza de São José de Macapá, já citadas. Em relação ao impacto na realidade social, a cidade preparava-se para se inserir no contexto nacional, criando infraestrutura para receber os servidores públicos vindo de outras regiões, visitantes e investidores, e considerando providências para diminuir a defasagem educacional que existia entre a região e as demais do país. 

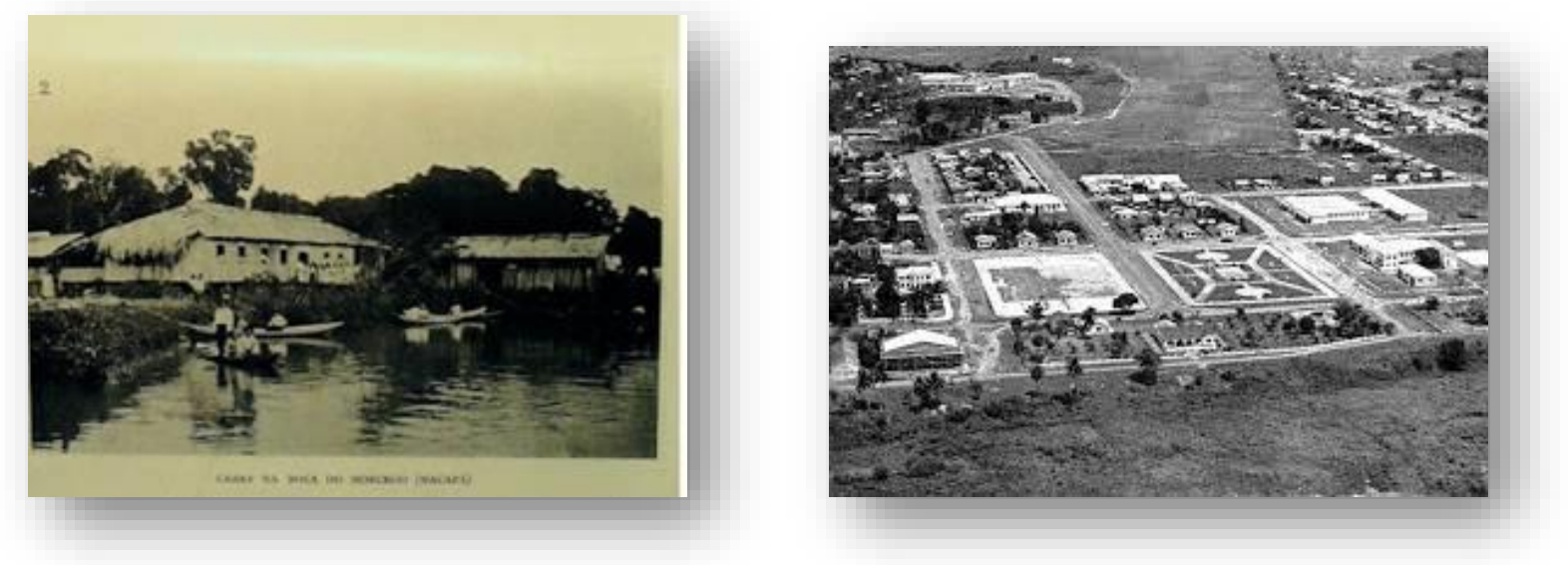

Imagem 19 - Casas na Boca do Morcego - Macapá.

Imagem 20 - Vista Aérea da cidade de Macapá, anos 50.

Acervo: G. Fidanze, Relatório do Governo do Pará,

Fonte: LOBATO, 2013, p.38.

Governador Augusto Montenegro, 1908.

A Macapá colonial, simples e ribeirinha pretendeu-se tornar moderna, complexa, institucionalizada e cresceu gradativamente com as costas voltadas para o rio. A expansão posterior promoveu novas leituras da cidade, não apenas através de sua arquitetura e de seu urbanismo, mas também dos diversos grupos sociais que a ocuparam e a transformaram, levando-nos a pensar não em Macapá, mas em "Macapás".

Finalizo frisando a importância da reflexão sobre a história da cidade, esta que agora passa por um outro processo de modernização, a verticalização. É através da análise do passado da cidade, de todas as transformações que ela sofreu e o que elas geraram para a sua população, que podemos enxergar o melhor caminho para a sua evolução no futuro e traçar planos de ação para a melhoria da qualidade de vida de seus habitantes.

\section{REFERÊNCIAS}

ARAÚJO, Renata Malcher de. As cidades da Amazônia no século XVIII: Belém, Macapá e Mazagão. 2. ed. Porto: FAUP/Publicações - cidade do Porto, 1998.

- A Urbanização da Amazônia e do Mato Grosso no século XVIII: Povoações civis, decorosas e úteis para o bem comum da coroa e dos povos. Anais do Museu Paulista. São Paulo. N. Sér. v.20. n.1. p. 41-76. jan.- jun. 2012.

BARBOSA, Coaracy Sobreira. Personagens Ilustres de Macapá. Amapá: Departamento de Imprensa Oficial. V.I, 1997.

BARTHES, Roland. A Câmara Clara. Rio de Janeiro: Nova Fronteira, 1984.

CANTO, Fernando Pimentel. Literatura das Pedras: a Fortaleza de São José de Macapá como Lócus das Identidades Amapaenses. Macapá: UNIFAP, 2017.

COSTA, L. Registro de uma vivência. Rio de Janeiro: Empresa das Artes, 1995.

GUERRA, Amanda Estela; SANTOS, Márcia Maria Duarte dos. O “Atlas do Império do Brazil”: uma proposta de definição dos limites do Brasil no século XIX. IV Simpósio Luso-Brasileiro de Cartografia Histórica. Porto: 2011.

FABRIS, Annateresa. O Desafio do Olhar: Fotografia e artes visuais no período das vanguardas históricas. V.II. São Paulo: Editora WMF Martins Fontes, 2013.

FLUSSER, Villém. A Filosofia da Caixa Preta: ensaios para uma futura filosofia da fotografia. São Paulo: Editora Hucitec, 1985. 
KOSSOY, Boris. Fotografia e História. São Paulo: Ática, 1989.

LOBATO, Sidney. Educação na fronteira da modernização: A política educacional no amapá (1944-1956). Belém: Paka-Tatu, 2009.

A cidade dos trabalhadores: Insegurança estrutural e táticas de sobrevivência em Macapá.São

Paulo: Universidade de São Paulo, 2013.

LUNA, Veronica Xavier. Um Cais que abriga histórias de vida: Homens e máquinas construindo o social na cidade de Macapá (1943-1970). Macapá: Unifap, 2017.

MARQUES, Indira Cavalcante da Rocha. Território Federal e mineração de manganês: gênese do Estado do Amapá. Tese (Doutorado em Geografia) - Universidade Federal do Rio de Janeiro, Instituto de Geociências, Rio de Janeiro, 2009.

MARTINS, Herbert Toledo. A fragmentação do Território Brasileiro: A criação de novos Estado no Brasil. Caderno CRH,n 35, p.253-288, jul/dez. 2001.

MONTEIRO, Maurílio de Abreu. A ICOMI no Amapá: meio século de exploração mineral. Novos Cadernos NAEA.v. 6 , n . 2 , p. 113 -168, dez. 2003.

NUNES, Janary Gentil. Relatório de Atividades do Governo do Território Federal do Amapá, em 1944, apresentado ao Excelentíssimo Senhor Presidente da República pelo Capitão Janary Gentil Nunes, Governador do Território. Rio de Janeiro: Imprensa Nacional, 1946.

PORTO, Jadson Luís Rebelo. Desenvolvimento Geográfico Desigual da faixa de fronteira da Amazônia setentrional brasileira: Reformas da condição fronteiriça amapaense (19432013).Blumenau, FURB/PPGDR, 2014.

SILVA, Maura Leal da. O Território Imaginado: Amapá, de Território à autonomia política (19431988). Tese de doutorado defendida no PPGHIS - Programa de Pós-graduação em História da Universidade de Brasília. Brasília, 2017.

SONTAG, Susan. Ensaios sobre a fotografia. Rio de Janeiro: Arbor, 1983.

SOULAGES, François. A Estética da Fotografia: perda e permanência. São Paulo: Ed. SENAC, 2010. 